\section{Does Cryopreservation Affect the Biological Properties of Stem Cells from Dental Tissues? A Systematic Review}

Marcus Cristian Muniz Conde 1 , Luiz Alexandre Chisini' , Guillermo Grazioli2, Alejandro Francia2, Rodrigo Varella de Carvalho ${ }^{3}$, Jose Carlos Bernedo Alcázar ${ }^{1,4}$, Sandra Beatriz Chavez Tarquinio ${ }^{1,5}$, Flávio Fernando Demarco ${ }^{1,6}$
'Post-Graduate Program in Dentistry, School of Dentistry, Federal University of Pelotas, Pelotas, Brazil ${ }^{2}$ School of Dentistry, University of the Republic, Montevideo, Uruguay ${ }^{3}$ School of Dentistry - Faculdade Meridional IMED, Passo Fundo, Brazil ${ }^{4}$ Post-Graduate Program in Science and Material Engineering, Federal University of Pelotas, Pelotas, Brazil ${ }^{5}$ Department of Semiology and Clinics, Federal University of Pelotas, Pelotas, Brazil ${ }^{6}$ Post-Graduate Program in Epidemiology, Federal University of Pelotas, Pelotas, Brazil

Correspondence: Flávio Fernando Demarco Rua Gonçalves Chaves, $4575^{\circ}$ Piso, 96015-560, Pelotas, RS, Brasil. Tel: +55-53811-12528 e-mail: ffdemarco@gmail.com

Key Words: cryopreservation, mesenchymal stem cells, dental tissues, tooth banking, cell viability

\section{Introduction}

The discovery and isolation of responsive mesenchymal stem cells (MSC) from dental tissues (1-4) raised the possibility for developing new regenerative therapies. Such MSC populations possess high proliferative, self-renewal, and multipotency, expressing the ability to differentiate in tissues, such as fat, bone, cartilage, and neural cells. MSCs could proliferate in vitro, maintaining their differentiation capacity, for a limited period, ranging for 15 to 50 population doublings (5). Currently it is clear that the number of passaging reduces the differentiation potential and the capacity of proliferation (6). Cryopreservation comprises a key method to keep MSC at early passages maintaining their biological properties.

Cryopreservation relies on a complex balance established by a well-controlled cooling rate and the cryoprotectant agent's (CA) concentration $(7,8)$. Thus, a proper CA should allow water to leave the cell slowly enough to avoid impairment on cells' membranes, but sufficiently fast to avoid ice crystals formation inside the cell. Dimethyl sulfoxide (DMSO) - $\left(\mathrm{CH}_{3}\right)_{2} \mathrm{SO}$ - a polar aprotic solvent, is widely applied as CA. Due to its hydrophilic nature, DMSO induces the water output in an ideal speed reducing the heat stress during transition from liquid to solid state (8-11).
However, DMSO has been shown to be cytotoxic, since DMSO can decrease the MSC's ability to proliferate and differentiate post-thaw (11). Thus, researchers have been testing alternative substances, such as glycerol and ethyleneglycol and sugars such as sucrose and trehalose, due to their reduced cytotoxicity as CA (12). Such CAs are widely used in vitrification techniques, which are based on eliminating the phase-glazing glass transition through a fast-freezing process. After that, the solution is converted into an amorphous solid, which should be free from ice crystal. In addition, new specialized facilities, such as magnetic field freezers (13-16) and programed freezers (12), have been applied to improve cell biological properties and minimize the toxic effects of CA.

There is a lack of information regarding the behavior of well-characterized cryopreserved MSC from dental tissues (dental stem cells - DSC). MSCs come from tissues with specific-related characteristics containing a heterogeneous cells population (5), thus making the definition of the best CA or the best facilities to cryopreserve cells and tissues a hard task. Davies et al. (17) have shown that the effects of in vitro expansion, after 10\% DMSO cryopreservation, on the viability and differentiation capacity is cell-dependent. The objective of this study has been to systematically 
review the literature in order to identify the influence of different cryopreservation protocols over the biological properties of dental stem cells post-thaw.

\section{Material and Methods}

This systematic review was carried out according to PRISMA statement (18). To structure the research question

Table 1. Database syntax applied to investigate the selected MeSH terms and its respective entry terms. TS= (At the ISI Web of Knowledge it field searches into abstracts, keywords, and article titles)

\begin{tabular}{|c|c|c|}
\hline & & Search Syntaxes \\
\hline \multirow{16}{*}{ 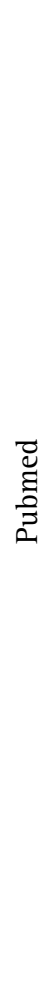 } & $\# 1$ & (Cryopreservation OR Cryofixation OR Vitrification) \\
\hline & $\# 2$ & $\begin{array}{l}\text { ("Adult AND Stem AND Cells" OR “Adult AND Somatic AND Stem AND Cell"” OR "Multipotent AND Stem } \\
\text { AND Cell"” OR "Mesenchymal AND Stromal AND Cells" OR "Mesenchymal AND Stem AND Cell") }\end{array}$ \\
\hline & \#3 & $\begin{array}{l}\text { (“Bone AND Marrow AND Mesenchymal Stem Cell*" OR "Blood Cord" } \\
\text { OR Hematopoietic OR "induced pluripotent stem cell*”) }\end{array}$ \\
\hline & $\# 4$ & (“Dental AND Pulp*” OR “Dental AND Pulp* AND Tissue*”) \\
\hline & \#5 & (“Periodontal AND Ligament” OR “Alveolodental AND Ligament”) \\
\hline & \#6 & (“Periapical AND Tissue"” OR “Apical AND Periodontium” OR “Apical AND Papilla” OR "Papilla AND Apical”) \\
\hline & \#7 & (“Tooth AND Germ*”) \\
\hline & \#8 & (“Dental AND Sac*” OR “Dental AND Follicle”) \\
\hline & $\# 9$ & (“Cell* AND Adhesion*”) \\
\hline & \# 10 & (“Cell* AND Differentiation”) \\
\hline & \# 11 & (“Cell* AND Proliferation” OR “Cellular AND Proliferation”) \\
\hline & \#12 & (“Dental AND Pulp AND Stem AND Cell*”) \\
\hline & \#13 & (“Periodontal AND Ligament AND Stem AND Cell“") \\
\hline & \#14 & (“Stem Cell* of Apical Papilla”) \\
\hline & \#15 & (“Human tooth germ stem cell*”) \\
\hline & \#16 & (“Stem Cell" from human exfoliated deciduous teeth") \\
\hline \multirow{16}{*}{ 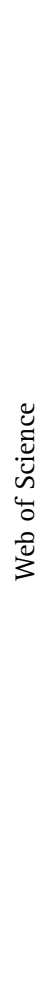 } & $\# 1$ & TS=(Cryopreservation OR Cryofixation OR Vitrification) \\
\hline & $\# 2$ & $\begin{array}{c}\text { TS }=((\text { Adult Stem Cells) OR (Adult Somatic Stem Cell*) OR (Multipotent Stem Cell*) } \\
\text { OR (Mesenchymal Stromal Cells) OR (Mesenchymal Stem Cell*)) }\end{array}$ \\
\hline & \#3 & $\begin{array}{c}\text { TS }=((\text { Bone AND Marrow AND Mesenchymal Stem Cell*) OR (Blood Cord) } \\
\text { OR Hematopoietic OR (Induced Pluripotent Stem Cell)) }\end{array}$ \\
\hline & \#4 & TS=((Dental AND Pulp*) OR (Dental AND Pulp* AND Tissue*)) \\
\hline & \#5 & TS=((Periodontal AND Ligament" OR “Alveolodental AND Ligament*)) \\
\hline & \#6 & TS=((Periapical AND Tissue*” OR “Apical AND Periodontium” OR “Apical AND Papilla” OR “Papilla AND Apical)) \\
\hline & \#7 & TS $=(($ Tooth AND Germ*) $)$ \\
\hline & \#8 & TS=((Dental AND Sac*” OR “Dental AND Follicle) $)$ \\
\hline & $\# 9$ & $\mathrm{TS}=(($ Cell $*$ AND Adhesion*) $)$ \\
\hline & $\# 10$ & $\mathrm{TS}=\left(\left(\right.\right.$ Cell ${ }^{*}$ AND Differentiation $\left.)\right)$ \\
\hline & \# 11 & TS $=((C e l l *$ AND Proliferation” OR “Cellular AND Proliferation $))$ \\
\hline & \#12 & TS $=(($ Dental AND Pulp AND Stem AND Cell*)) \\
\hline & \#13 & $\mathrm{TS}=(($ Periodontal AND Ligament AND Stem AND Cell*) $)$ \\
\hline & \#14 & TS $=\left(\left(\right.\right.$ Stem Cell ${ }^{*}$ of Apical Papilla $\left.)\right)$ \\
\hline & \#15 & $\mathrm{TS}=(($ Human tooth germ stem cell*) $)$ \\
\hline & \#16 & $\mathrm{TS}=\left(\left(\right.\right.$ Stem Cell ${ }^{*}$ from human exfoliated deciduous teeth $\left.)\right)$ \\
\hline
\end{tabular}


(Which is the influence of cryopreservation protocol over biological properties of stem cells obtained from dental tissues?) the PICO model has been applied. PICO stands for: Population: Stem cells from dental tissues; Intervention: Cryopreservation; Comparison: Fresh cells or tissues; Outcome: DSC biological properties (Cell survival rate (CSR), proliferation, differentiation, maintenance of stem cell markers).

As for eligibility criteria, the search was limited to: a) Experimental research articles; b) Studies evaluating the biological properties of previously cryopreserved DSC or cells isolated from previously cryopreserved dental tissues; c) Studies meeting the minimal criteria for MSC characterization as described by Dominici et al. (5).

As for exclusion criteria, the presented systematic review did not include studies evaluating the viability of cryopreserved MSC from tissues other than dental pulp, periodontal ligaments, apical papilla, and tooth germ.

Regarding the information sources, studies were identified by searching electronic databases, including PubMed (PM) and the ISI Web of Science ${ }^{\circledR}$ (IWS), up to April 2015. The keywords selected included relevant entry terms associated with each MeSH Term database and the search was developed considering the relevant entry terms associated with each MeSH Term (Table 1).

With respect to selection of studies and data collection, pre-selected keywords were combined to retrieve the studies (Table 2). The records retrieved have been uploaded into the ENDNOTE ${ }^{\circledR}$ basic (www.myendnoteweb.com) to delete the duplicated ones. Two independent reviewers read the titles and abstracts of all found reports considering the inclusion criteria to perform later the full report evaluation. For data collection, the full version of all included studies were obtained and the data were extracted (Table 3). If any disagreement was found in relation to the inclusion of some study, the reviewers discussed the matter to obtain consensus.

\section{Results}

The initial search (Fig. 1) resulted in 1773 initial records corresponding to 482 individual, from which 32 were selected by evaluating their title and abstract for complete reading. After that, 21 papers were selected for the data extraction (Table 3). Dental pulp stem cells (DPSC) were the most cryopreserved DSC (52\%). DMSO has been applied as CA in $100 \%$ of the selected studies, at concentrations

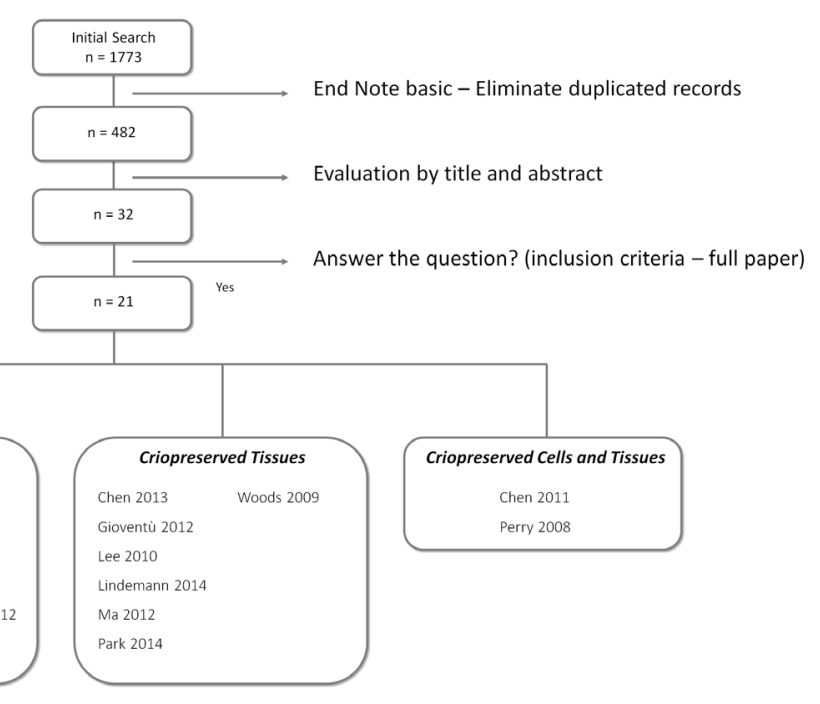

Figure 1. Flowchart from selected studies

Table 2. Keywords combination and records recovered in each database.

\begin{tabular}{lcc}
\hline \multirow{2}{*}{$\begin{array}{l}\text { Key words applied to develop } \\
\text { the search strategy }\end{array}$} & \multicolumn{2}{c}{ Records found } \\
\cline { 2 - 3 } & PubMed $^{\circledR}$ & $\begin{array}{c}\text { Web of } \\
\text { Sciecnce }\end{array}$ \\
\hline \#1 AND \#2 NOT 3 & 396 & 321
\end{tabular}

\# 1 AND \#2 AND \#4

$24 \quad 36$

\#1 AND \#2 AND \#5

$5 \quad 10$

\#1 AND \#2 AND \#6

\#1 AND \#2 AND \#7

3

10

\#1 AND \#2 AND \#8

$4 \quad 4$

\# 1 AND \#4

2

2

\#1 AND \#5

69

79

\#1 AND \#6

43

\# 1 AND \#7

5

\# 1 AND \#8

7

\# 1 AND \#12

6

\#1 AND \#13

50

\# 1 AND \# 14

14

\#1 AND \#15

\#1 AND \# 16

\# 1 AND \#2 AND \#9 NOT \#3

\# 1 AND \#2 AND \#10 NOT \#3

182

114 
between $3 \%$ and $20 \%(16,19,20)$. Only $19 \%$ of the included studies performed the cryopreservation for periods higher than one year (20-23). Specialized facilities (magnetic or programed freezers) were applied in 19\% of the studies $(12-14,16)$.
Biological Properties of Previously Cryopreserved Dental Stem Cells: Selected studies (Table 3) showed that the applied cryopreservation protocols, in periods ranging from $24 \mathrm{~h}$ up to 2 years, have been allowed to recover DSC presenting suitable biological properties (5). DMSO in a

Table 3. Studies matching the inclusion criteria selected for data extraction full text selected for data extraction

\begin{tabular}{|c|c|c|c|c|c|}
\hline Study & Stem Cells & Cell Source & Cryopreservation tecnique & Cryoprotector & FBS content \\
\hline \multirow{2}{*}{$\begin{array}{l}\text { Seo } \\
(3)\end{array}$} & \multirow[t]{2}{*}{ PDLSC } & \multirow[t]{2}{*}{$3^{\text {rd }}$ molar } & $\begin{array}{l}\text { Fast Freezing } \\
3 \text { or } 6 \text { months }\end{array}$ & DMSO $10 \%$ & $90 \%$ \\
\hline & & & $-196^{\circ} \mathrm{C} \mathrm{N}_{2}$ & & \\
\hline \multirow{2}{*}{$\begin{array}{l}\text { Papaccio } \\
(21)\end{array}$} & \multirow[t]{2}{*}{ DPSCs } & \multirow[t]{2}{*}{ Human teeth } & $\begin{array}{c}\text { Did not described } \\
2 \text { years }\end{array}$ & \multirow[t]{2}{*}{ DMSO $10 \%$} & \multirow[t]{2}{*}{$20 \%$} \\
\hline & & & $-196^{\circ} \mathrm{C} \mathrm{N}_{2}$ storage & & \\
\hline $\begin{array}{l}\text { Ding } \\
(25)\end{array}$ & SCAPs & $3^{\text {rd }}$ Molar & $\begin{array}{l}\text { Slow Freezing } \\
6 \text { months }\end{array}$ & $\begin{array}{c}\text { DMSO } 10 \% \\
\text { G } 10 \% \\
\text { EG } 10 \%\end{array}$ & $90 \%$ \\
\hline
\end{tabular}

$4^{\circ} \mathrm{C}$ for $1 \mathrm{~h}$, then at $-20^{\circ} \mathrm{C}(2 \mathrm{~h}) ;-80^{\circ} \mathrm{C}$ (Overnight.) $-196^{\circ} \mathrm{C} \mathrm{N}_{2}$ storage.

Yalvac

TGSCs

$3^{\text {rd }}$ molar germs

Slow Freezing

10\% DMSO

$20 \%$

(30)

$-80{ }^{\circ} \mathrm{C}$ for 6 months

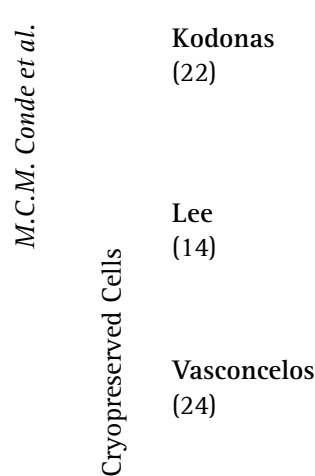

sDPSCs

Dental pulp Slow freezing

10\% hetastarch,
human albumin,

1 year

DMSO

RT to $-7^{\circ} \mathrm{C}\left(1.5^{\circ} \mathrm{C} / \mathrm{min}\right) ;-7^{\circ} \mathrm{C}$ to $-40^{\circ} \mathrm{C}\left(0.5^{\circ} \mathrm{C} / \mathrm{min}\right) ;-40^{\circ} \mathrm{C}$ to $-100^{\circ} \mathrm{C}\left(6^{\circ} \mathrm{C} / \mathrm{min}\right) ;-196^{\circ} \mathrm{C}$

\begin{tabular}{|c|c|c|c|}
\hline DPSCs & Incisors & $\begin{array}{c}\text { Slow Freezing - MF } \\
1 \text { Week }\end{array}$ & DMSO 0-10\% \\
\hline
\end{tabular}

MF: $-5^{\circ} \mathrm{C} 15 \mathrm{~min} ;-5^{\circ} \mathrm{C}$ to $-32^{\circ} \mathrm{C}\left(-0.5^{\circ} \mathrm{C} / \mathrm{min}\right) ;-150^{\circ} \mathrm{C} \mathrm{MF}$; The DPSCs in the Non MF were frozen in an isopropanoljacketed freezing container $-80^{\circ} \mathrm{C}$ freezer overnight and subsequently stored in a $-150^{\circ} \mathrm{C}$ freezer for 1 week

$\begin{array}{lcc}\text { PDLSC } & \text { Slow Freezing } & \text { DMSO } \\ 3^{\text {rd }} \text { Molar } & 1 \text { month } & 90 \%\end{array}$

$2 \mathrm{~h}$ at $4^{\circ} \mathrm{C}, 18 \mathrm{~h}$ at $-20^{\circ} \mathrm{C},-85^{\circ} \mathrm{C}$

Dogan TGSCs $\quad 3^{\text {rd }}$ Molar

Slow Freezing
6 months

DMSO 10\%, FBS

$20 \%$, and $1 \%$ of

PSA and $0.05 \%$

Pluronic 188 (F68)

$-20^{\circ} \mathrm{C}$ for $15 \mathrm{~min} ;-80^{\circ} \mathrm{C}$ overnight; $-196^{\circ} \mathrm{C}$

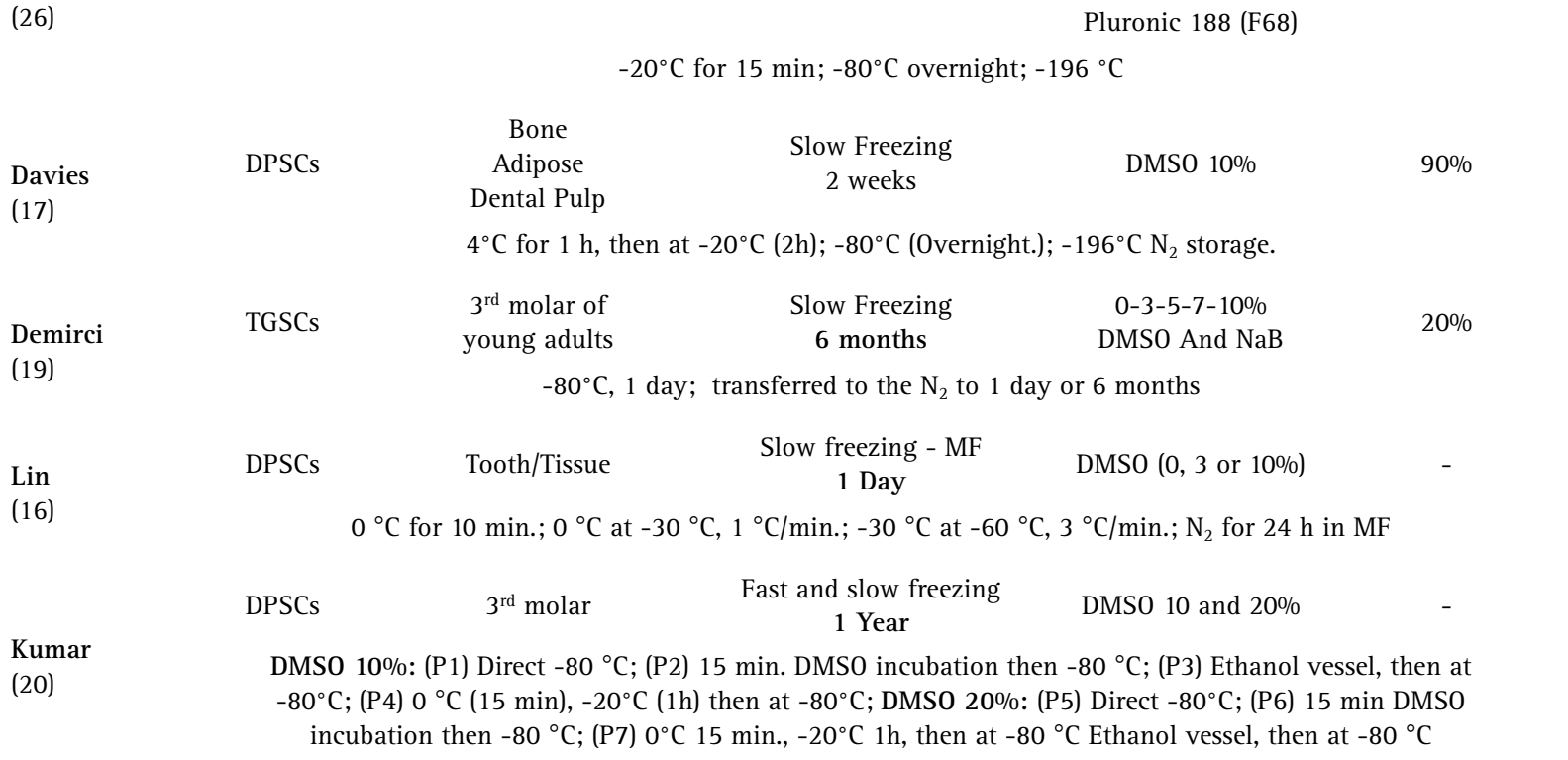




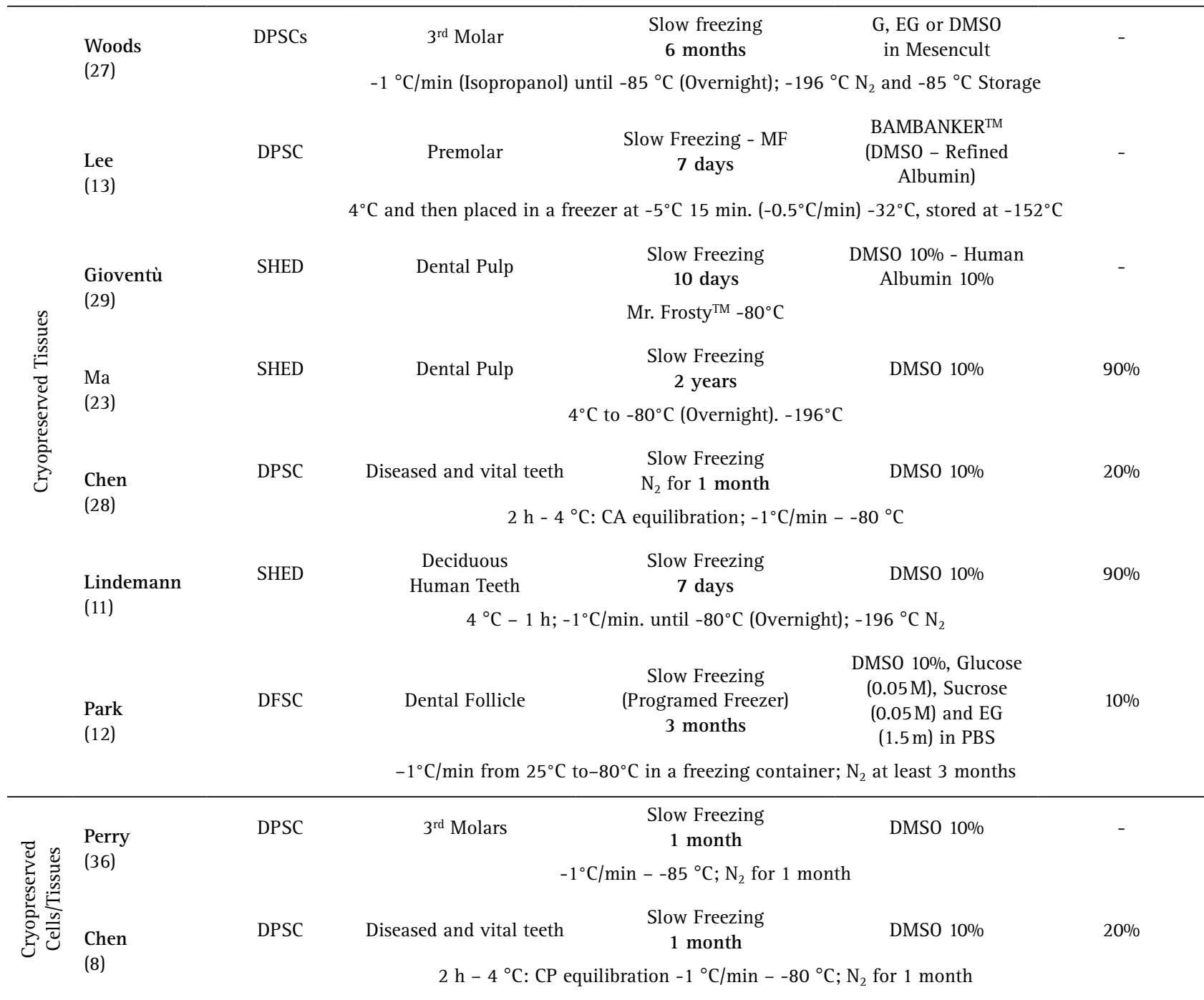

${ }^{\circ} \mathrm{C}$ - Degree Celsius; ${ }^{\circ} \mathrm{C} / \mathrm{min}$ - Degree Celsius per minute; CA - Cryoprotectant agent; DFSC - Dental Foicle Stem Cells; DMSO - Dimethyl sulfoxide; DPSC - Dental Pulp Stem Cells; EG - Ethylene Glycol; FBS - Fetal Bovine serum; G - Glycerol; h - Hours; M - Molar; MF - Magnetic Freezing; min - Minute; N2 - Liquid Nitrogen; NaB - Boran Nitrate; PDLSC - Periodontal Ligament Stem Cells; PSA - Penicillin-streptomicyn-anpicillin; RT - Room Temperature; SCAP - Stem Cells from Apical Papilla; sDPSC - Suine Dental Pulp Stem Cells; SHED - Stem Cells from Human Exfoliated deciduous teeth; T - Tesla; TGSC - Tooth Germ Stem Cells; PBS - Phosphate Buffered Saline; NR - Not reported

concentration of $10 \%$ has been the most applied CA for DPSC $(14,20-22,24)$. Besides, it was possible to cryopreserve DPSC by the fast-freezing technique $\left(-80{ }^{\circ} \mathrm{C}\right)$ for up to 1 year, thus eliminating the pre-freezing steps (20). Lower DMSO concentration 3\% (DPSC) and 5\% (Human Tooth Germ Stem Cells - HTGSC) were effective to maintain cell biological properties when cryopreserved into a magnetic field freezer (14) or by adding $\mathrm{NaB}(20 \mu \mathrm{g})$ to CA (19). DSC cryopreserved with $10 \%$ glycerol and 10\% ethylene glycol $(12,25)$ presented similar cell biological properties when compared to those cryopreserved with 10\% DMSO. When Pluronic 188 (F68) was incorporated into 10\% DMSO, a slight improvement in HTGSC viability was reported (26).

Biological Properties of Stem Cells Isolated from Previously Cryopreserved Dental Tissues: Selected studies depicted to be possible isolate viable DSC from previously cryopreserved dental tissues. DPSC isolated from cryopreserved dental pulps, for up to 2 years in $\mathrm{N}_{2}$ $(11,13,23,27,28)$, has been able to retain their ability to differentiate and express mesenchymal stem cell surface markers. In addition, pulp tissues' cryopreservation, for up to 6 months at $-85^{\circ} \mathrm{C}$ mechanical freezer, has been shown to be a viable option to store DPSC (27). $10 \%$ or $15 \%$ DMSO has not been deleterious for DSC biological properties, being better than vitrification agents such as glycerol and ethylene glycol (27). However, a modified cryoprotectant ( $0.05 \mathrm{~m}$ glucose, $0.05 \mathrm{~m}$ sucrose and $1.5 \mathrm{~m}$ ethylene glycol) allowed $>70 \%$ of the survival rate of human follicle stem cells after 3 months of tissue storage (12). The cells from cryopreserved human dental follicles (HDFSC) expressed 
mesenchymal stem cell markers in a manner similar to fresh cells (12). Moreover, it has been possible to isolate viable DPSCs from diseased 6 month-cryopreserved pulp tissue (8); DPSCs has been able to maintain their biological properties and differentiate toward hepatic cells (28).

DPSC obtained from whole-tooth cryopreserved dental pulps has been shown a small recuperation rate (20\%) $(8,27)$. However, DPSC has been successfully recovered when the whole tooth has been submitted to a previous treatment with a Nd:YAG laser beam to generate microchannels across the enamel and dentin layers, improving the cryoprotectant diffusion until the pulp tissue (29).

\section{Discussion}

The presented systematic review has shown If DSC are cryopreserved after their isolation, then the biological properties such as CSR, adhesion ability, high proliferation rate, and differentiation ability (multipotency), remains quite similar to those observed in non-cryopreserved DSC. All of included studies applied DMSO in different concentration and 10\% DMSO was the most-applied CA, providing post-thaw CSR above 90\%. Interestingly, we could observe that DMSO concentrations under $10 \%$ were suitable for DPSC cryopreservation, thus allowing DPSC survival $\left(-85^{\circ} \mathrm{C}\right.$ or $\left.\mathrm{N}_{2}-196^{\circ} \mathrm{C}\right)(27)$ and normal karyotype maintenance (30).

The drawback related to DMSO consists on its inherent cytotoxicity, which would be detrimental for cell viability (31); thus it has been emphasized the need to reduce DMSO concentrations to ensure maximum cell yield post-thaw. However, Kumar et al. (20) after evaluating eight different DMSO-based cryopreservation for DPSC (Table 3), could recover, in every tested protocols, DPSC able to differentiate in adipose-, osteoblast- and neural-like cells. They could conclude that uncontrolled freezing (fast freezing) at $-80^{\circ} \mathrm{C}$ has been as effective as controlled freezing (slow freezing), independently of DMSO concentration (20). Furthermore, $15 \%$ DMSO allowed the survival of DPSC from previously cryopreserved dental pulp tissues $\left[-80^{\circ} \mathrm{C}\right.$ mechanical freezer or $\mathrm{N}_{2}-196^{\circ} \mathrm{C}$ for 6 months] (27). In both studies $(20,27)$, every evaluated cell population has been retained their stemness surface markers (CD-90, CD-105, CD-73, CD-34, CD-45, CD-11b, CD-19, and HLA-DR) post-thaw depicting multipotency ability. DMSO concentrations up to $5 \%$ were effective (CSR $\geq 90 \%$ ) when associated to chemical reagents or specific facilities producing magnetic fields $(14,19)$. Demirci et al. (19) showed that 5\% DMSO supplemented with $\mathrm{NaB}$ provided a CSR similar to 10\% DMSO, when HTGSC has been cryopreserved.

Ice crystal formation starts in temperatures between 0 and $4^{\circ} \mathrm{C}$ (31) generating a weak electric current which is able to disrupt cell membranes affecting CSR post- thaw. Magnetic fields could exert a positive influence during MSC cryopreservation since prevent ice crystal formation by allowing the water molecules to be instantly frozen. DSC's CSR in a DMSO-free environment has been increased 2 or 2.5 fold, depending on the configuration of the magnetic field (16). The addition of trehalose as CA's additive has not been improved DMSO's performance during cryopreservation of dental pulp or intact teeth under magnetic field (15). Thus, considering the limitations related to the selected studies, is possible to hypothesize that lower DMSO concentration and shorter preequilibration time are needed when cryopreservation is performed in magnetic-emitting field freezer. In fact, Lee Huang et al. (14) has been shown that DPSC's biological properties post-thaw, such as viability, adhesion, proliferation, MSC surface markers expression and multipotency, were quite similar after cryopreservation with 10\% DMSO in a regular freezer or 3\% DMSO, FBS-free medium, in a magnetic field; both DSC population presented lower rates of apoptotic cells, suggesting a freezing process with less cell damage under magnetic fields.

Another important factor to be considered during cryopreservation is the fetal bovine serum (FBS) concentration applied. FBS possess a central role in maintaining biological properties reducing the risk of cell damage during freezing and thawing cycles (32). FBS comprises a complex mixture of growth factors, proteins, carbohydrates, cytokines, and indispensable nutrients for cell development in vitro (33). In fact, high FBS concentration (90\%) has induced less cell damage when compared to concentration under $90 \%$ concentration in animal cells (32). However, there is a concern regarding FBS due to risk related to pathogens transmissions and internalization of animal's proteins, which can unleash antigenic responses in the patient post-DSC implantation (34). FBS content protein remain present in human cells after consecutive cell washings (34) and may change the cell surface markers even as induce unforeseen modification of cell biology (35). Due to such characteristics, FBS is not recommended in studies aiming to perform Stem CellBased Therapy (SC-BT) for clinical transition. A free-FBS cell-freezing (DMEM, 10\% hetastarch, human albumin, DMSO) allowed for cryopreservation of swine DSCs for one year. Cryopreserved swine DSCs were positive for CD90, CD105, and CD146 (22). Besides, a commercially available FBS-medium (Cryostor-CS-10), worked as well as DMEM containing 10\% FBS (27).

When $10 \%$ DMSO was compared to another CAs, $10 \%$ glycerol and 10\% ethylene glycol, a similar effect was observed for SCAP cell viability, colony-forming efficiency (25). In addition, DPSC has been cryopreserved in different concentrations $(0.5 \mathrm{M}-1.5 \mathrm{M})$ of ethylene glycol, propylene 
glycol, or DMSO (1 month - LN2). The DPSC viability cryopreserved in 1.0 M DMSO (90.6\%) and 1.5 M DMSO $(91.0 \%)$ were significantly better than the other CAs at corresponding concentrations. A modified CA (0.05 M glucose, $0.05 \mathrm{M}$ sucrose and 1.5 M ethylene glycol in PBS) allowed for previously cryopreserved DFCS present a CSR of $70 \%$ (16). Furthermore, chemical-like pluronic 188-F68 was slight better than DMSO 10\% in preserving HSTG viability after 6 months of cryopreservation (26).

The cryopreservation of previous isolated DSCs seems to be a process that maintains the proliferation and differentiation ability of these cells. It was interesting to note that is possible to store the teeth, after extraction, for up to $120 \mathrm{~h}$ in $\mathrm{PBS}\left(-4^{\circ} \mathrm{C}\right)$ to obtain high proliferative DPSCs (36). It was also possible to recover $70 \%$ of DPSCs from a cryopreserved whole tooth after one month in liquid nitrogen (36). Conversely, other studies showed that only small rates (around 20\%) of viable DPSCs could be retrieved from cryopreserved healthy (27) or diseased teeth (8). To be effective, the CA must penetrate by passive diffusion into the whole tissue $(27,36)$, which is affected by the surface area available for CA contact. A tooth is constituted by highly mineralized tissues surrounding the dental pulp, which presents just the apical foramen for CA access the pulp. To obtain viable cells from the pulp tissue, the apical foramen from human teeth should have a minimum dimension of $9.42 \mathrm{~mm}^{2}$ (37) to allow preservation agents to be effective. Cells isolated from the apical (root) portion of rat teeth showed a high CSR when compared with cells from the other two sections-the middle and the coronal (15). Another alternative to improve the CA diffusion is to build up artificial openings to improve the CA diffusion through dental tissues. Gioventu et al. (29) showed that cells from cryopreserved teeth, submitted to previous laser-piercing (the coronal portion), showed mesenchymal stem cells' morphology, immunophenotype, viability, and a proliferation rate similar to those cells from non-cryopreserved teeth.

This systematic review depicted that DSC could be cryopreserved, mainly with DMSO [10\% - 20\%], for periods up to 2 years maintaining their high proliferation rate, multipotency, karyotype and stem cells surface markers. The whole tooth cryopreservation (to isolate DSC) seemed to be a not reliable method and future investigation are needed in this filed. On the other hand, the cryopreservation of the intact pulp tissue seemed to constitute an attractive and reliable source to isolate DPSC. It could be valuable since avoids the immediate stem isolation before cryopreservation. However, evaluated cryopreservation times evaluated in selected studies has been too short; just 19\% of the included studies have been evaluated the cryopreservation for periods longer than one year. Thus, the behavior of DSC in long times storage cannot be securely predicted. The conclusions presented in this systematic review should be interpreted with caution.

\section{Resumo}

Essa revisão sistemática avaliou se diferentes protocolos de criopreservação podem afetar as propriedades biológicas (taxa de sobrevivência celular, proliferação, diferenciação, manutenção dos marcadores de superficie) de células-tronco isoladas de tecidos dentais (DSC) após o descongelamento. Uma busca eletrônica foi realizada no PubMed e no ISI Web of Science utilizando palavras-chave especificas. Dois revisores independentes avaliaram os títulos e resumos de todos os estudos respeitando critérios de inclusão e exclusão previamente determinados. Os dados foram extraídos considerando as propriedades biológicas de DSC, e DSC isoladas de tecidos previamente criopreservados. DSC criopreservadas logo após seu isolamento apresentaram propriedades biológicas muito semelhantes às observadas em DSC não criopreservadas. Dimetil sulfóxido (DMSO) [10\%] demonstrou bons resultados relacionados com a recuperação celular após descongelamento de células e tecidos, por periodos de até 2 anos. A criopreservação de DSC em freezer mecânico $\left(-80^{\circ} \mathrm{C}\right)$ permite a recuperação de células-tronco pós-descongelação. A utilização de freezer com campo magnético (MF), proporciona a utilização de uma menor concentração de crioprotector, mas a sua utilização não é dispensável. É possivel isolar e criopreservar e criopreservar células-tronco da polpa dental (DPSC) de dentes vitais saudáveis e doentes. Criopreservação de tecidos dentais após o isolamento de DSC, combinados com MF, podem ser valiosas estratégias para reduzir custos e melhorar a logistica no desenvolvimento de bancos de dentes.

\section{References}

1. Gronthos S, Mankani M, Brahim J, Robey PG, Shi S. Postnatal human dental pulp stem cells (DPSCs) in vitro and in vivo. Proc Natl Acad Sci U S A 2000;97:13625-13630.

2. Miura M, Gronthos S, Zhao M, Lu B, Fisher LW, Robey PG, et al. SHED: stem cells from human exfoliated deciduous teeth. Proc Natl Acad Sci U S A 2003;100:5807-5812.

3. Seo BM, Miura M, Gronthos S, Bartold PM, Batouli S, Brahim J, et al. Investigation of multipotent postnatal stem cells from human periodontal ligament. Lancet 2004;364:149-155.

4. Sonoyama W, Liu Y, Yamaza T, Tuan RS, Wang S, Shi S, et al. Characterization of the apical papilla and its residing stem cells from human immature permanent teeth: a pilot study. J Endod 2008;34:166171.

5. Dominici M, Le Blanc K, Mueller I, Slaper-Cortenbach I, Marini F, Krause $D$, et al. Minimal criteria for defining multipotent mesenchymal stromal cells. The International Society for Cellular Therapy position statement. Cytotherapy 2006;8:315-317.

6. Park YB, Kim YY, Oh SK, Chung SG, Ku SY, Kim SH, et al. Alterations of proliferative and differentiation potentials of human embryonic stem cells during long-term culture. Exp Mol Med 2008;40:98-108.

7. Dissanayake SC, Che ZM, Choi SH, Lee SJ, Kim J. Evaluation of vitrification for cryopreservation of teeth. J Periodontal Implant Sci 2010;40:111-118.

8. Chen YK, Huang AH, Chan AW, Shieh TY, Lin LM. Human dental pulp stem cells derived from different cryopreservation methods of human dental pulp tissues of diseased teeth. J Oral Pathol Med 2011;40:793800.

9. Oh YH, Che ZM, Hong JC, Lee EJ, Lee SJ, Kim J. Cryopreservation of human teeth for future organization of a tooth bank--a preliminary study. Cryobiology 2005;51:322-329.

10. Ahn SJ, Jang JH, Seo JS, Cho KM, Jung SH, Lee HW, et al. Influence of 2 cryopreservation methods to induce CCL-13 from dental pulp cells. J Endod 2013;39:1562-1566.

11. Lindemann D, Werle SB, Steffens D, Garcia-Godoy F, Pranke P, Casagrande L. Effects of cryopreservation on the characteristics 
of dental pulp stem cells of intact deciduous teeth. Arch Oral Biol 2014;59:970-976.

12. Park BW, Jang SJ, Byun JH, Kang $\mathrm{YH}$, Choi MJ, Park WU, et al. Cryopreservation of human dental follicle tissue for use as a resource of autologous mesenchymal stem cells. J Tissue Eng Regen Med 2014.

13. Lee SY, Chiang PC, Tsai YH, Tsai SY, Jeng JH, Kawata T, et al. Effects of cryopreservation of intact teeth on the isolated dental pulp stem cells. $J$ Endod 2010;36:1336-1340.

14. Lee SY, Huang GW, Shiung JN, Huang YH, Jeng JH, Kuo TF, et al. Magnetic cryopreservation for dental pulp stem cells. Cells Tissues Organs 2012;196:23-33.

15. Lee SY, Sun CH, Kuo TF, Huang YH, Jeng JH, Yang JC, et al. Determination of cryoprotectant for magnetic cryopreservation of dental pulp tissue. Tissue Eng Part C Methods 2012;18:397-407.

16. Lin SL, Chang WJ, Lin CY, Hsieh SC, Lee SY, Fan KH, et al. Static magnetic field increases survival rate of dental pulp stem cells during DMSO-free cryopreservation. Electromagn Biol Med 2015;34:302-308.

17. Davies OG, Smith AJ, Cooper PR, Shelton RM, Scheven BA. The effects of cryopreservation on cells isolated from adipose, bone marrow and dental pulp tissues. Cryobiology 2014;69:342-347.

18. Moher D, Liberati A, Tetzlaff J, Altman DG. Preferred reporting items for systematic reviews and meta-analyses: the PRISMA statement. PLoS Med 2009;6:e1000097.

19. Demirci S, Dogan A, Sisli B, Sahin F. Boron increases the cell viability of mesenchymal stem cells after long-term cryopreservation. Cryobiology 2014;68:139-146.

20. Kumar A, Bhattacharyya S, Rattan V. Effect of uncontrolled freezing on biological characteristics of human dental pulp stem cells. Cell Tissue Bank 2015;16:513-522.

21. Papaccio G, Graziano A, d'Aquino R, Graziano MF, Pirozzi G, Menditti $D$, et al. Long-term cryopreservation of dental pulp stem cells (SBPDPSCs) and their differentiated osteoblasts: a cell source for tissue repair. J Cell Physiol 2006;208:319-325.

22. Kodonas K, Gogos C, Papadimitriou S, Kouzi-Koliakou K, Tziafas D. Experimental formation of dentin-like structure in the root canal implant model using cryopreserved swine dental pulp progenitor cells. J Endod 2012;38:913-919.

23. Ma L, Makino $Y$, Yamaza $H$, Akiyama $K$, Hoshino $Y$, Song G, et al. Cryopreserved dental pulp tissues of exfoliated deciduous teeth is a feasible stem cell resource for regenerative medicine. PLoS One 2012;7:e51777.

24. Vasconcelos RG, Ribeiro RA, Vasconcelos MG, Lima KC, Barboza CA. In vitro comparative analysis of cryopreservation of undifferentiated mesenchymal cells derived from human periodontal ligament. Cell Tissue Bank 2012;13:461-469.

25. Ding G, Wang W, Liu $Y$, An $Y$, Zhang $C$, Shi $S$, et al. Effect of cryopreservation on biological and immunological properties of stem cells from apical papilla. J Cell Physiol 2010;223:415-422.
26. Dogan A, Yalvac ME, Yilmaz A, Rizvanov A, Sahin F. Effect of F68 on cryopreservation of mesenchymal stem cells derived from human tooth germ. Appl Biochem Biotechnol 2013;171:1819-1831.

27. Woods EJ, Perry BC, Hockema JJ, Larson L, Zhou D, Goebel WS. Optimized cryopreservation method for human dental pulp-derived stem cells and their tissues of origin for banking and clinical use. Cryobiology 2009;59:150-157.

28. Chen YK, Huang AH, Chan AW, Lin LM. Human dental pulp stem cells derived from cryopreserved dental pulp tissues of vital extracted teeth with disease demonstrate hepatic-like differentiation. J Tissue Eng Regen Med 2013.

29. Gioventu S, Andriolo G, Bonino F, Frasca S, Lazzari L, Montelatici E, et al. A novel method for banking dental pulp stem cells. Transfus Apher Sci 2012;47:199-206.

30. Yalvac ME, Ramazanoglu M, Tekguc M, Bayrak OF, Shafigullina $A K_{\text {, }}$ Salafutdinov, II, et al. Human tooth germ stem cells preserve neuroprotective effects after long-term cryo-preservation. Curr Neurovasc Res 2010;7:49-58.

31. Kaku M, Kamada H, Kawata $T$, Koseki H, Abedini S, Kojima $S$, et al. Cryopreservation of periodontal ligament cells with magnetic field for tooth banking. Cryobiology 2010;61:73-78.

32. Renzi $S$, Lombardo $T$, Dotti $S$, Dessi SS, De Blasio P, Ferrari M. Mesenchymal stromal cell cryopreservation. Biopreserv Biobank 2012;10:276-281.

33. Fekete N, Rojewski MT, Furst D, Kreja L, Ignatius A, Dausend J, et al. GMP-compliant isolation and large-scale expansion of bone marrowderived MSC. PLoS One 2012;7:e43255.

34. Haque N, Kasim NH, Rahman MT. Optimization of pre-transplantation conditions to enhance the efficacy of mesenchymal stem cells. Int $J$ Biol Sci 2015;11:324-334.

35. Mannello F, Tonti GA. Concise review: no breakthroughs for human mesenchymal and embryonic stem cell culture: conditioned medium, feeder layer, or feeder-free; medium with fetal calf serum, human serum, or enriched plasma; serum-free, serum replacement nonconditioned medium, or ad hoc formula? All that glitters is not gold! Stem Cells 2007;25:1603-1609.

36. Perry BC, Zhou D, Wu X, Yang FC, Byers MA, Chu TM, et al. Collection, cryopreservation, and characterization of human dental pulp-derived mesenchymal stem cells for banking and clinical use. Tissue Eng Part C Methods 2008;14:149-156.

37. Temmerman L, Beele H, Dermaut LR, Van Maele G, De Pauw GA Influence of cryopreservation on the pulpal tissue of immature third molars in vitro. Cell Tissue Bank 2010;11:281-289.

Received April 15, 2016 Accepted August 12, 2016 